\title{
The Trust and Fundraising Issues in the Muslim Community
}

\section{Noor Muafiza Masdar, Rohaida Basiruddin and Yunita Fitria}

To Link this Article: http://dx.doi.org/10.6007/IJARBSS/v12-i1/11986

DOI:10.6007/IJARBSS/v12-i1/11986

Received: 07 November 2021, Revised: 10 December 2021, Accepted: 27 December 2021

Published Online: 13 January 2022

In-Text Citation: (Masdar et al., 2022)

To Cite this Article: Masdar, N. M., Basiruddin, R., \& Fitria, Y. (2022). The Trust and Fundraising Issues in the Muslim Community. International Journal of Academic Research in Business and Social Sciences, 12(1), 994 -1000 .

\section{Copyright: @ 2022 The Author(s)}

Published by Human Resource Management Academic Research Society (www.hrmars.com)

This article is published under the Creative Commons Attribution (CC BY 4.0) license. Anyone may reproduce, distribute, translate and create derivative works of this article (for both commercial and non0-commercial purposes), subject to full attribution to the original publication and authors. The full terms of this license may be seen at: http://creativecommons.org/licences/by/4.0/legalcode

Vol. 12, No. 1, 2022, Pg. $994-1000$

Full Terms \& Conditions of access and use can be found at http://hrmars.com/index.php/pages/detail/publication-ethics 


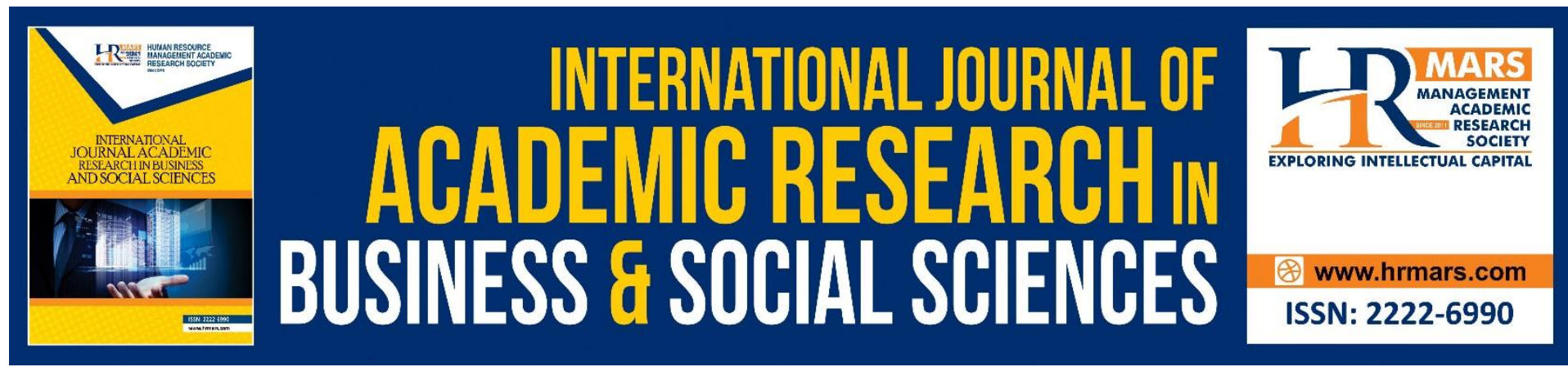

\title{
The Trust and Fundraising Issues in the Muslim Community
}

Noor Muafiza Masdar ${ }^{1}$, Rohaida Basiruddin ${ }^{2}$ and Yunita Fitria ${ }^{3}$

${ }^{1}$ Azman Hashim International Business School, Universiti Teknologi Malaysia, Jalan Sultan Yahya Petra, 54100, Federal Territory of Kuala Lumpur, Malaysia; and Labuan Faculty of International Finance, Universiti Malaysia Sabah, Jalan Sungai Pagar, 87000, Federal

Territory of Labuan, Malaysia, ${ }^{2}$ Azman Hashim International Business School, Universiti

Teknologi Malaysia, Jalan Sultan Yahya Petra, 54100, Federal Territory of Kuala Lumpur, Malaysia, ${ }^{3}$ Fakultas Ekonomi and Bisnis, Universitas Mulawarman, Jl. Kuaro, Gn. Kelua, Kec.

Samarinda Ulu, Kota Samarinda, Kalimantan Timur, 75119, Indonesia.

Email:muafiza@ums.edu.my,rohaida.kl@utm.edu.my,yunita.fitria@feb.unmul.ac.id

\begin{abstract}
Trust is synonym with the fragile issue but really in need for every humankind to have it. Trust somehow will bring individuals or organizations to raise funds easily by convincing people through good communication and sympathy. However, this situation might lead to harm when the receiver misused the fundraised and ultimately will give a negative impact on the public at large. Due to this matter, this study aims to understand the trust development in raising funds among the Muslim community. This study had interviewed six (6) people from different backgrounds to understand the trust that they had before and after giving funds to the individual or to the organization. By looking at the theory of trust, this study found trust becomes a religious persuasion among the Muslim community. It becomes a norm for helping others with the belief to receive rewards from God on the day of judgment. Therefore, trust has a powerful connection towards fundraising issues in the Muslim community.
\end{abstract}

Keywords: Trust, Charity Organization, Fundraising, Individual, Muslim Community

\section{Introduction}

The word of trust is highly connected to the social interaction between an individual or group of people from one to another (Mark Weber et al., 2005). Trust can be developed towards individuals, the community, and organizations. It could be trusted in terms of monetary basis or in terms of projects development. Trust issues become sensible especially when its incurred fund collected either physical or online transactions (Chiu et al. 2012; Grabner-kraeuter 2002; Hsiao et al. 2010). Unlike trust issues in the corporate organization that has an underlying asset to be trading for their investor (Fassas, 2012), trust towards charity organization shows a different story.

The charity organization could raise their fund to millions of money without contributors investing for the dividend for return of investment (Connolly and Hyndman, 2015; Cordery and Baskerville, 2011; Mcconville, 2018). The issue comes across when 
contributors have trust toward a person or organization, which organization in this study is referring to the charity organization that does not hold any shareholder for specific investment purposes. The number of funds is kept raising even though during the covid-19 pandemic. Here, the trust issue becomes a central need to be justified especially among the Muslim community because this community is among the largest contributors to others (Yasmin et al., 2014). Due to this matter, this study aims to understand the way in which trust has been developed in raising funds among the Muslim community. This study intends to find out on any matters to be figured out as a trusted development that incurred monetary basis.

\section{Literature Review \\ Trust and Trust Development}

The word trust is so sensible for everyone and it became an essential role for the organization (Yoon, 2014). Based on trust, the organizations can be sustainable in the middle of problems. There are two areas of trust (R. Lewicki, 2014), namely professional and personal. Professional can be related to the organization in terms of task and organizations' objective. Then, personal relates to the emotion in relationships. Indeed, the form of trust needs both professional and personal part in individual or organizations.

Trust development is a process to receive all risks (Mark Weber et al., 2005). It begins when one party does action on that trust and until gaining benefits for the relationship. (R. J. Lewicki et al., 2006) claimed that trust needs to observe the actor behaviour which can be detected from cooperative behaviour. Active trust development can be determined as the strategy (Child and Mo, 2003). It means the active relationship between personal or organizations can improve trust.

\section{The Theory of Trust}

Trust means to receive all risks in the process of a relationship. The theory Luhmann and Barber present "trust as an irreducible and multidimensional social reality" (Lewis et al., 1985). It means trust can be seen through the relationship process. Trust can be positioned in a specific environment (Cordery and Baskerville, 2011; Hyndman and Mcconville, 2017; Lewis et al., 1985; Li et al., 2006), in many conditions which have mutual relationship appearing trust as a basic contract.

There are studies about trust in charity in several communities (Jing and Qing, 2017; McCarthy, 2013; Przygoda, 2019; Yasmin et al., 2014). They present different mechanisms of charity in terms of religion. Przygoda (2019) claimed that charitable action is part of the Church mission which implies mercy from God. Christian community affirms that faith is essential for organizations (McCarthy, 2013). Indeed, faith is the power of religion. Islam and Christian emphasize to accountability and trust in their mission (Yasmin et al., 2014).

Besides the Christian community, Buddhist charity also has activities in supporting the social sector (Jing and Qing, 2017). In general, the communities help the livelihood of children. Furthermore, in the Islamic perspective trust or Amanah should become a charity organization (Yasmin et al., 2014) because we must perform accountability to God and also to society.

\section{Methodology}

This study is using a qualitative approach to understanding the trust development of individuals and organizations. A qualitative study has been chosen because it allows the researcher to have a deep understanding of the trust issue before and after the fund has been 
disseminated among the Muslim community. The data collection technique of this study is an interview with an individual who is the one channel the money and interview with the personnel from the charity organization which they are the one who receives the money for assisting those in need. The data collected then been analysed by using NVivo 12 for coding management where ultimately theme will be developed from the saturated coding.

\section{Findings and Discussion}

The trust among the Muslim community has a strong connection with faith and belief in the ultimate God. Muslims believe in the reward given by God whenever they performed a good deed and assist others.

"I am not really care on what they will do with the money I donated, I just sincerely gave to them and it's up to them want to do whatever that they like" (Contributor A, 021).

"I donated to the organization ... I sincere to donate without asking directly what they want to do with the money ... sometimes I checked their social media ... but, most of the time no" (Contributor B, 2021).

"I always donate to this organization ... Even though I am not really clear on what they are doing with my donation, but I feel want to give without question" (Contributor C, 2021).

An individual contributor seems not to care about the purpose of money transferred to the receiver, regardless the receiver is an individual or organization. The generous feeling to make a donation becomes a habit for some people in the Muslim community.

"We received lots of money from random people ... We cannot trace all of them ... We do communicate with some of them that we are able to contact ... They do trust us as they do" (Organization 1, 2021).

"We gave them awareness about the current situation faced by our brothers and sisters out there ... We talk sincerely ... They donate to us" (Organization 2, 2021).

"We give speech in the Mosque ... Many people in the mosque listened to our talk ... We disseminate the fund box ... We gained many fund from this approach" (Organization 3, 2021).

There are many ways trust can be developed by the charity organization to the fund contributors. One of the main approaches by giving awareness to the community. This awareness is delivered through a physical meeting during a speech tour in the mosque. This method allows charity organizations to raise funds randomly from various contributors that perform religious obligations at the mosque.

Other than that, information shared through social media also enables charity organizations to raise funds. Published information such as pictures and awareness on the needy could raise more attention and sympathy by the user of social media. This situation 
automatically creates empathy among the Muslim community and ultimately funds will be transferred to the charity organizations silently without knowing who are the contributors and without detailed face-to-face explanation by the organizations to the contributors.

\section{Trust As a Religious Persuasion to the Muslim Community}

Trust becomes a powerful element among the Muslim community because it relates to the belief that doing a good deed will receive a reward from God. Contributors treat the trust as a religious persuasion in the Muslim community. Giving money or helping others becomes a must for Muslim brotherhood without concern about the background and detailed explanation of the receiver. Not limited to the reward, the behaviour of doing a good deed is embedded by the awareness of the livelihood of those in need. Awareness becomes a powerful tool in developing trust and in raising funds from contributors. This awareness is really effective especially during speech tours in the Mosque or religious institutions. It becomes a strategy for a charity organization to give awareness and to raise funds for the purpose of assisting those in need (Fitria, 2017). Unlike the Muslim community that treated trust in giving funds as a religious persuasion, other religions have a different perspective in treating trust (Yasmin et al., 2014), Christian community (McCarthy, 2013), Buddhism community (Jing and Qing, 2017).

In western countries like the United Kingdom, comprehensive documentation and procedure should be followed by the charity organization before they can raise funds from any contributors regardless of individual or organization (Dhanani and Connolly, 2012). The strict regulation from the regulator makes the community in that particular country have a weak level of trust (Weber et al., 2005). However, most developed countries treated fundraising for helping others as a norm and common behaviour (Connolly and Hyndman, 2015; Yasmin et al., 2014). This is because they have in mind that everybody survives in their life and it should be cooperation between the contributors and the receivers (Lewis et al., 1985). Thus, trust in developing countries remains easy to achieve. Similar situation in developing countries, most Arab communities in the Middle East countries also treated trust in giving funds for assisting those in need as a religious persuasion and they are demand a reward from God (Abouassi and Trent, 2016). This situation remains quite similar due to majority of the Muslim community are living in Middle East countries (Abouassi and Trent, 2016).

Trust is fragile and to develop it requires a social reality and strongly believes in one ideology. Once the trust has been developed, it will last for long period and remain sustained as a norm in the community. Therefore, this study found trust in the Muslim community is treated as a religious persuasion due to the belief in God's reward towards the fund contributors.

\section{Conclusion}

The fundraising issue is closely related to the trust development among fund contributors towards the receiver regardless the receiver is an individual or organization. Thus, this study found Muslim community is easily developing trust due to religious persuasion. The belief that God will reward a good deed from helping people make the trust development sensible and happen in many places in Muslim countries. However, this study is limited to data collection of the Muslim community solely. Thus, this study will be more fruitful if other religious perspectives to be included, such as community from Christianity, 
Buddhism, and et cetera. The inclusion of various religious perspectives will give robust data and understanding on the trust development towards fundraising issue.

\section{References}

Abouassi, K., \& Trent, D. L. (2016). NGO ACCOUNTABILITY FROM AN NGO PERSPECTIVE : PERCEPTIONS, STRATEGIES, AND PRACTICES. 296, 283-296. https://doi.org/10.1002/pad

Chi, T., \& Chi, T. (2013). Buddhism and Its Trust Networks between Taiwan, Malaysia, and the United States. 59-76.

Child, J., \& Mo, G. (2003). Contextual Confidence and Active Trust Development in the Chinese Business Environment. ORGANIZATION SCIENCE, 14(1), 69-80. https://doi.org/10.1287/orsc.14.1.69.12813

Chiu, C., Hsu, M., Lai, H., \& Chang, C. (2012). Re-examining the in fl uence of trust on online repeat purchase intention: The moderating role of habit and its antecedents. Decision Support Systems, 53(4), 835-845. https://doi.org/10.1016/j.dss.2012.05.021

Connolly, C., \& Hyndman, N. (2015). Charity accountability in the UK: through the eyes of the donor. March. https://doi.org/10.1108/QRAM-02-2013-0006

Cordery, C. J., \& Baskerville, R. F. (2011). Charity Transgressions, Trust and Accountability Related papers. Voluntas, 22, 197-213. https://doi.org/10.1007/s11266-010-9132-x

Dhanani, A., \& Connolly, C. (2012). Discharging not-for-profit accountability: UK charities and public discourse. Accounting, Auditing and Accountability Journal, 25(7), 1140-1169. https://doi.org/10.1108/09513571211263220

Fassas, A. P. (2012). Exchange-Traded Products investing and Precious Metal prices. Journal of Derivatives \& Hedge Funds, 18(2), 127-140. https://doi.org/10.1057/jdhf.2012.3

Fitria, Y. (2017). Akuntabilitas pada Organisasi Religi; Studi Kasus Masjid-Masjid di Balikpapan, Kalimantan Timur. Akuntabel, 14(1), 38. https://doi.org/10.29264/jakt.v14i1.1353

Grabner-kraeuter, S. (2002). The Role of Consumers' Trust in Online-Shopping. Journal of Business Ethics, 39, 43-50.

Hsiao, K.-L., Chuan-Chuan Lin, J., Wang, X.-Y. W., Lu, H.-P., \& Yu, H. (2010). Antecedents and consequences of trust in online product recommendations an empirical study in social shopping trust in online product. Online Information Review, 34(6), 1468-4527. https://doi.org/10.1108/14684521011099414

Hyndman, N., \& Mcconville, D. (2017). Trust and accountability in UK charities : Exploring the virtuous circle. The British Accounting Review.

https://doi.org/10.1016/j.bar.2017.09.004

Jing, C., \& Qing, L. (2017). The Background, Dilemma and Path for Buddhist Charities to Engage in Social Protection of the Children in Plight. The China Nonprofit Review, 9, 337358. https://doi.org/10.1163/18765149-12341336

Lewicki, R. (2014). Trust, Trust Development, and Trust Repair. January 2000.

Lewicki, R. J., Tomlinson, E. C., \& Gillespie, N. (2006). Models of Interpersonal Trust Development: Theoretical Approaches, Empirical Evidence, and Future Directions. Journal of Management, 32(6), 991-1022. https://doi.org/10.1177/0149206306294405

Lewis, J. D., Weigert, A., \& Dame, U. N. (1985). Trust as a Social Reality *. 1, 967-985.

Li, J. J., Zhou, K. Z., Lam, S. S. K., \& Tse, D. K. (2006). Active trust development of local senior managers in international subsidiaries. 59, 73-80.

https://doi.org/10.1016/j.jbusres.2005.02.005

Mark Weber, J., Malholtra, D., \& Keith Murnighan, J. (2005). Normal Acts of Irrational Trust: 
Motivated Attributions and The Trust Development Process. Research in Organizational Behavior, 26, 75-101.

McCarthy, S. K. (2013). Serving Society, Repurposing the State: Religious Charity and Resistance in China. The China Journal, 70, 48-72.

Mcconville, D. (2018). Making charity effectiveness transparent: Building a stakeholderfocussed framework of reporting. December 2015, 1-15.

https://doi.org/10.1111/faam.12148

Przygoda, W. (2019). The Mercy of God as the Foundation of Charity of the Church. Diacovensia, 27, 637-651.

Sunier, T. (2021). Islam, locality and trust: making Muslim spaces in the Netherlands. https://doi.org/10.1080/01419870.2020.1851738

Taylor, C. B. (2018). Accounting for piety in modern North India. 1, 266-296.

Watson, G. W., \& Papamarcos, S. D. (2002). SOCIAL CAPITAL AND ORGANIZATIONAL COMMITMENT. 16(4), 537-552.

Yasmin, S., Haniffa, R., \& Hudaib, M. (2014). Communicated Accountability by Faith-Based Charity Organisations. Journal of Business Ethics, 122(1), 103-123. https://doi.org/10.1007/s10551-013-1759-2

Yoon, A. (2014). End users' trust in data respositories: definitionand influences on trust development. Archival Science, 14, 17-34. https://doi.org/10.1007/s10502-013-9207-8 